\title{
DETEKSI Liberibacter spp. PADA JERUK SIAM BERGEJALA KLOROSIS DISERTAI BERCAK HITAM DENGAN Polymerase Chain Reaction
}

\author{
Iliana $^{1}$, Rahmawati $^{{ }^{* *}}$, Agus Rachmat $^{2}$, Mukarlina $^{1}{ }^{1}$ Latiffah Zakaria $^{3}$ \\ ${ }^{1}$ Program Studi Biologi, Fakultas Matematika dan Ilmu Pengetahuan Alam, Universitas Tanjungpura \\ Jl. Prof. Dr. H. Hadari Nawawi, Pontianak, Kalimantan Barat, Indonesia \\ ${ }^{2}$ Laboratorium Genomik dan Perbaikan Mutu Tanaman, Pusat Penelitian Bioteknologi, Lembaga Ilmu Pengetahuan \\ Indonesia, Cibinong, Bogor 14430, Jawa Barat, Indonesia \\ ${ }^{3}$ School of Biological Sciences, Universiti Sains Malaysia, 1800 USM, Pulau Pinang Malaysia \\ *email: $\underline{\text { rahmawati@,fmipa.untan.ac.id }}$
}

\begin{abstract}
Liberibacter bacteria are one of the pathogenic bacteria in citrus plants. Siam Citrus Plant in Setapok Village, Singkawang City, suspected to be infected with Liberibacter spp. bacteria by showing patterns of symptoms of chlorosis accompanied by patches. This study aims to detect Liberibacter spp. on Siam Citrus leaves with symptomatic chlorosis with patches. Leaf sampling uses the roaming method in one of the citrus plantations in Setapok Village, Singkawang City. Detection of Liberibacter spp. done by PCR (Polymerase Chain Reaction) technique. Detection of bacterial DNA through several stages namely, isolation of bacterial plasmid DNA, 16S rDNA gene amplification with a thermocycler machine, and visualization using a set of electrophoresis devices. Electrophoresis results show the presence of DNA band lines, with a size of around $1100 \mathrm{bp}$ for OI1 and OI2c primers, and DNA bands of 703 bp for A2 and J5 specifics. The results showed that there were Liberibacter spp. in the symptomatic chlorosis of Siam Citrus leaves accompanied by patches.
\end{abstract}

Keywords: Chlorosis, DNA, Liberibacter spp., PCR, Siam Citrus

\section{PENDAHULUAN}

Liberibacter spp. merupakan salah satu bakteri patogen pada tanaman jeruk. Bakteri Liberibacter termasuk anggota dari subdivisi Proteobacteria yang bersifat patogen dan termasuk kelompok bakteri gram negatif (Jagoueix et al., 1997). Berbagai macam penyakit yang ditemukan pada tanaman jeruk memiliki pola gejala yang ditimbulkannya. Penyakit yang sering ditemui oleh para petani jeruk di Indonesia adalah penyakit yang disebebkan oleh infeksi bakteri patogen Liberibacter spp. dengan gejala daun menguning (klorosis), warna tulang daun menjadi tua, daun menjadi kaku, lebih tebal dan ukurannya menjadi kecil (Wijaya, 2007).

Selain itu penyakit lainnya pada tanaman jeruk adalah kanker jeruk yang disebabkan oleh bakteri patogen Xanthomonas axonopodis pv. Citri yang ditandai gejala bercak putih pada sisi bawah daun, warna hijau gelap dan kadang berwarna kuning dipinggiran daun tepi bercak berwarna kuning (halo kuning) yang akan berubah menjadi coklat hitam dan terbentuknya lesi nekrotik (Davies \& Albrigo, 2003). Bakteri patogen Liberibacter sulit dideteksi jika hanya menggunakan metode konvensional. Menurut Hung et al. (1999), deteksi bakteri patogen Liberibacter penyebab CVPD (Citrus Vein Phloem Degeneration) dengan gejala klorosis dan tulang daun menjadi hijau tua (vein banding), secara konvensional pada media agar kurang memberikan hasil yang memuaskan karena rendahnya konsentrasi bakteri di dalam jaringan tanaman dan distribusinya yang tidak merata.

Salah satu metode yang dapat digunakan untuk mendeteksi keberadaan bakteri pada tanaman adalah PCR (Polymerase Chain Rection) yaitu teknik modern untuk mengidentifikasi makhluk hidup sampai ke tingkat molekuler dengan cara mensintesis dan menggandakan potongan DNA hingga berjuta kali lipat dalam waktu yang relatif singkat (Schaad et al., 2001). Metode ini sangat 
sensitif dan memiliki akurasi yang tinggi meskipun kosentrasi bakteri di dalam jaringan tanaman sangat rendah jumlahnya (Jagoueix et al., 1996). Gen 16S rDNA digunakan sebagai parameter sistematik molekular yang universal untuk mendeteksi keberadaan bakteri secara representatif dan praktis dalam mengkonstruksi kekerabatan filogenetik pada tingkat spesies (Case et al., 2007). Salah satu tanaman jeruk yang paling banyak dibudidayakan adalah Jeruk Siam (Citrus nobilis var microcarpa) yang mendominasi sekitar 60\% dipasar nasional seperti di Kalimantan Barat, Kalimatan Selatan, Jawa Barat, Bali dan Sulawesi Tenggara (Dirjenhorti, 2002). Komoditas buah Jeruk Siam di Kalimantan Barat memiliki sentra perkebunan di Kabupaten Sambas dan Kota Singkawang. Penyakit pada tanaman Jeruk Siam yang ditemukan di perkebunan jeruk Kota Singkawang memiliki pola gejala klorosis, bercak hitam yang dikelilingi bercak hitam.

Berdasarkan gejala yang tampak pada daun tanaman Jeruk Siam tersebut, maka penting dilakukan penelitian terkait isolasi dan deteksi bakteri patogen pada tanaman dengan metode PCR menggunakan primer spesifik 16S rDNA untuk mengetahui penyebab spesifik penyakit pada tanaman Jeruk Siam yang ada di sentra perkebunan Kota Singkawang. Penelitian ini bertujuan untuk mendeteksi bakteri Liberibacter spp. pada daun Jeruk Siam yang bergejala klorosis disetai bercak. Penelitian ini di harapkan dapat memberikan informasi ilmiah kepada pembaca dan petani jeruk mengenai bakteri patogen Liberibacter spp. pada tanaman Jeruk Siam, beserta pola gejala yang ditimbulkannya. Selain menjadi dasar acuan untuk penelitian selanjutnya dengan upaya pencegahan dan pengendalian terhadap bakteri patogen CVPD maupun dengan kajian yang lebih mendalam.

\section{BAHAN DAN METODE}

\section{Waktu dan Tempat Penelitian}

Penelitian ini dilaksanakan pada bulan Agustus hingga Oktober 2019. Pengambilan sampel daun jeruk di perkebunan jeruk Desa Setapok, Kota Singkawang. Isolasi DNA, amplifikasi gen $16 \mathrm{~S}$ rDNA dan Visualisasi elektroforesesis dilakukan di Laboratorium Genomik dan Perbaikan Mutu Tanaman (GPMT) Pusat Penelitian Bioteknologi, Lembaga Ilmu Pengetahuan Indonesia (LIPI) Cibinong, Bogor, Jawa Barat.

\section{Alat dan Bahan}

Alat-alat yang digunakan dalam penelitian ini adalah alat tulis, alumunium foil, bunsen, skalpel (mata pisau), camera, cetakan jel agarose, cawan petri, duram $500 \mathrm{ml}$, erlenmeyer, flashdisk, gelas baker, gelas ukur, gunting, karet, kertas foto, kertas saring, kulkas, laminar air flow, lateks, mesin PCR (Biometra), microwave, mikropipet, nanophotometer, neraca analitik, oven, pinset, plastik, rak tube, elektroforesis, sisir agarose, sentrifuse, tabung durham, tips mikropipet, tissu kering, tube 1,5 ml, UV transilluminator (UVITEC) dan vortex. Bahan bahan yang digunakan untuk isolasi DNA adalah akudest, alkohol 70\%, buffer solution (Tris-cl pH 8 $1 \mathrm{M}$, EDTA $0,5 \mathrm{M}$, glukosa $0,5 \mathrm{M}$, NaoH $10 \mathrm{M}$, SDS $20 \%$ dan $\mathrm{dH}_{2} \mathrm{O}$ ), batu es, CH3COONA $3 \mathrm{M} \mathrm{pH} \mathrm{7,}$ daun jeruk, ETOH 70\%, ETOH absolute (96\%) TE $\mathrm{pH} 8$, dan water Dnase Rnase-free $\left(\mathrm{dH}_{2} \mathrm{O}\right)$. Bahan yang digunakan untuk amplifikasi dan visualisasi yaitu dreamtag EtBr, gel agarose, lamda DNA/Hind III marker, primer forward dan reverse OI1/OI2c, primer A2/J5, dan TBE 0,5x.

\section{Cara Kerja}

\section{Pengambilan sampel}

Sampel daun Jeruk Siam (Citrus nobilis var. microcarpa) yang digunakan dalam penelitian ini diambil dari perkebunan jeruk di Desa Setapok, Kecamatan Singkawang, Kota Singkawang, Kalimantan Barat. Sampel daun jeruk diambil menggunakan metode jelajah. Daun Jeruk Siam yang diambil adalah daun yang bergejala penyakit CVPD dengan pengamatan secara visual, kemudian diambil dan dimasukkan ke dalam plastik bening lalu disimpan di kotak pendingin. Sampel dibawa ke Laboratorium GPMT Puslit Bioteknologi LIPI dan disimpan di freezer dengan suhu $-80^{\circ} \mathrm{C}$.

\section{Isolasi DNA Plasmid}

Isolasi DNA plasmid dalam penelitian ini merupakan modifikasi dari metode alkalin lisis dengan prinsip utama yaitu pelisisan sel, ekstraksi DNA plasmid, presipitasi dan purifikasi DNA plasmid (Sambrook \& Russell, 2001). Sampel daun dikultur dengan tahapan berikut: daun jeruk dimasukkan ke dalam tabung yang sudah berisi alkohol 70\% selama 1 menit, setelah itu dicuci dengan akuades steril sebanyak 3 kali pengulangan yang dilakukan di dalam laminar air flow, kemudian disiapkan petri yang berisi kertas saring dan dikeringkan daun jeruk di atas kertas saring 
tersebut. Daun jeruk dipotong kecil-kecil, dan disiapkan microtube berukuran 1,5 ml, lalu dimasukkan media LB (Luria bertani) cair ke dalam tabung tersebut. Daun yang sudah dipotong dimasukkan ke dalam tube yang sudah berisi media LB, kemudian diinkubasi di oven (firlabo) pada suhu $37^{\circ} \mathrm{C}$ selama 2-3 hari hingga bakterinya tumbuh.

Tahapan selanjutnya dilakukan isolasi DNA plasmid bakteri dengan menyiapkan kultur dari DNA bakteri lalu disentrifuse pada $12.000 \mathrm{rpm}$ selama 2 menit, dan dibuang supernatannya. Masing-masing tube ditambahkan $100 \mu 1$ larutan I yang terdiri dari Tris-cl pH $81 \mathrm{M}$, EDTA $0,5 \mathrm{M}$, glukosa $0,5 \mathrm{M}$ dan $\mathrm{dH} 2 \mathrm{O}$, lalu diinkubasi di es selama 15 menit. Selanjutnya ditambahkan lagi $200 \mu 1$ larutan II yang terdiri dari $\mathrm{NaoH} 10 \mathrm{M}$, SDS $20 \%$ dan $\mathrm{dH}_{2} \mathrm{O}$ lalu diinkubasi di es selama 15 menit, setelah itu setiap tube ditambahkan larutan $\mathrm{CH}_{3} \mathrm{COONA}$ sebanyak $150 \mu \mathrm{l}$ dan diinkubasi di es selama 15 menit. Kemudian disentrifuse pada $10.000 \mathrm{rpm}$ selama 5 menit, diambil supernatan dengan mikropipipet $200 \mu \mathrm{l}$ dan ditambahkan $1 \mathrm{ml} \mathrm{ETOH}$ absolut (96\%), lalu disentrifuse pada $10.000 \mathrm{rpm}$ selama 5 menit dengan suhu $4{ }^{\circ} \mathrm{C}$.

Pelet dicuci dengan ETOH $70 \%$ sebanyak $500 \mu 1$ setiap tube, dibuang supernatan dan dikeringkan pelet. Setelah kering pelet dilarutkan dengan $20 \mu \mathrm{l}$ TE atau $\mathrm{dH}_{2} \mathrm{O}$, (sesuai kebutuhan) dan disimpan pada suhu $-20{ }^{\circ} \mathrm{C}$. Setelah proses isolasi DNA, dilanjutkan dengan pengukuran konsentrasi dan kemurnian DNA menggunakan nanophotometer. DNA yang sudah diukur konsentrasinya, diencerkan dengan water, Dnase, Rnase-free $\left(\mathrm{dH}_{2} \mathrm{O}\right)$, sehingga mendapatkan konsentrasi yang seragam untuk digunakan dalam analisis PCR.

\section{Amplifikasi Gen $16 S$ rDNA}

Amplifikasi gen 16S rDNA menggunakan primer spesifik 16S rDNA untuk deteksi bakteri patogen Liberibacter asiaticus. Primer spesifik yang digunakan yaitu primer OI1 (forward) (5'GCGCGTATGCAAGAGCGGCA-3') dan primer OI2c (reverse) (5'GCCTCGCGACTTCGCAACCCAT3', serta primer A2 (forward) (5' TATAAAGGTTGACCTTTCGAGTTT-3') dan primer J5 (reverse) (5'ACAAAA GCAGAAATAGCACGAACAA-3') (Hocquellet et al., 1999). DNA template hasil isolasi sebanyak $1 \mu 1$ diamplifikasi menggunakan mesin PCR dengan volume total reaksi sebanyak $12,5 \mu 1$. Reaksinya terdiri dari $1 \mu 1$ DNA template, $1 \mu 1$ forward primer, dan $1 \mu 1$ reverse primer, $6,25 \mu \mathrm{PCR}$ master mix solution (dreamtag) dan 3,25 $\mu 1$ free water. Tahapan amplifikasi DNA dilakukan sebagai berikut: a) Perlakuan awal pada suhu $95{ }^{\circ} \mathrm{C}$ selama 5 menit dengan satu siklus ulangan, b) Empat puluh siklus yang terdiri atas pemisahan utas DNA (Denaturation) pada suhu $94{ }^{\circ} \mathrm{C}$ selama 1 menit, c) penempelan primer pada DNA (Annealing) pada suhu 55$60{ }^{\circ} \mathrm{C}$ selama 30 detik, d) Sintesis DNA (Elongation) pada suhu $72{ }^{\circ} \mathrm{C}$ selama 1 menit, e) Penyesuaian utas atas dan bawah (Extention) pada suhu $72{ }^{\circ} \mathrm{C}$ selama 5 menit.

Visualisasi DNA dengan Elektroforesis

DNA bakteri hasil amplifikasi divisualisasi dengan seperangkat elektroforesis menggunakan gel agarosa $0.8 \%$ (dalam TBE $0,5 \times$ ) yaitu sebanyak 2,4 gram agarose dilarutkan dalam $300 \mathrm{ml}$ TBE $0,5 \mathrm{X}$, dan dipanaskan di dalam mikrowave selama 2-3 menit hingga larut. Kemudian didiamkan hingga suhunya hangat, lalu dituang pada cetakan gel agarose yang sudah disiapkan. Setelah gel agarose padat dipindahkan pada alat elektroforesis, selanjutnya DNA hasil PCR dimasukkan ke dalam sumuran agarose sebanyak $12,5 \mu 1$ dan lamda DNA/HindIII marker sebanyak $5 \mu$ pada sumur pertama sebagai marker ukuran band DNA.

Kemudian dielektroforesis pada tegangan 100 volt selama 60 menit, menggunakan seperangkat alat elektroforesis (Biorad). Hasil elektroforesis direndam dalam EtBr selama 15 menit dan dibilas air mengalir selama 5 menit lalu DNA dilihat dengan UV transilluminator dan difoto dengan kamera digital. Indikator adanya bakteri adalah apabila terdapat pita DNA, maka dikatakan positif mengandung bakteri patogen L. asiaticus.

\section{Penyajian data}

Data yang diperoleh dianalisis secara deskriptif. Kemudin disajikan dalam bentuk gambar berupa ukuran pita DNA bakteri. Garis pita DNA pada hasil elektroforesis menunjukkan reaksi positif terhadap patogen L. asiaticus.

\section{HASIL DAN PEMBAHASAN}

\section{Hasil}

Penelitian yang telah dilakukan berhasil mendeteksi keberadaan bakteri patogen Liberibacter asiaticus di dalam jaringan daun tanaman Jeruk Siam yang bergejala klorosis disertai bercak hitam (Gambar 1). 
Deteksi terhadap bakteri patogen ini dengan menggunakan sepasang primer spesifik 16S rDNA, yaitu OI1 (forward) dan OI2c (reverse) yang mengamplifikasi pita DNA sekitar 1100 bp (Gambar 2), serta primer spesifik A2 (forward) dan J5 (reverse) dengan target protein ribosomal yang mengamplifikasi pita DNA sekitar 703 bp (Gambar 3) pada saat divisualisasi.

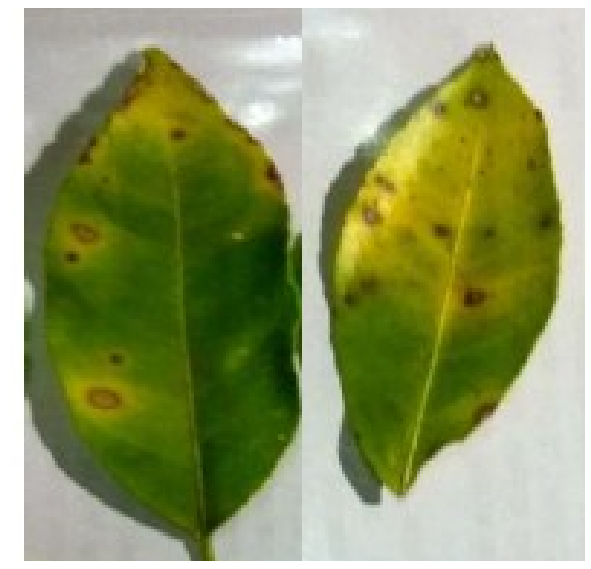

Gambar 1. Gejala penyakit pada daun Jeruk Siam di Desa Setapok, Kota Singkawang (klorosis disertai bercak hitam.

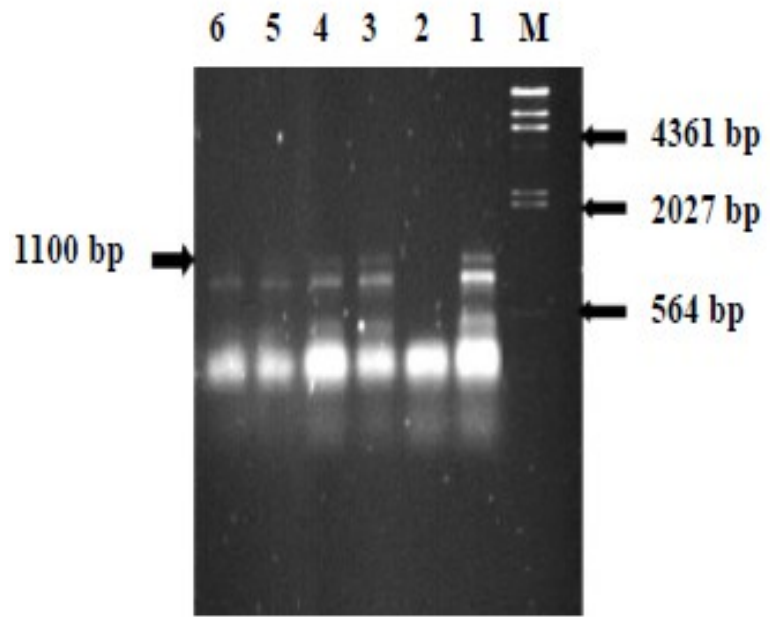

Gambar 2. Hasil elektroforesis pada gel agarosa 0,8\% DNA yang diamplifikasi dengan primer OI 1 (forward) dan OI2c (reverse) dari DNA diekstraksi pada daun jeruk yang terinfeksi penyakit (jalur 1), kontrol air/ kontrol negatif (jalur 2), DNA diekstraksi dari daun jeruk yang terinfeksi dengan penyakit (jalur 3,4,5,6). M: lamda DNA/HindIII marker.

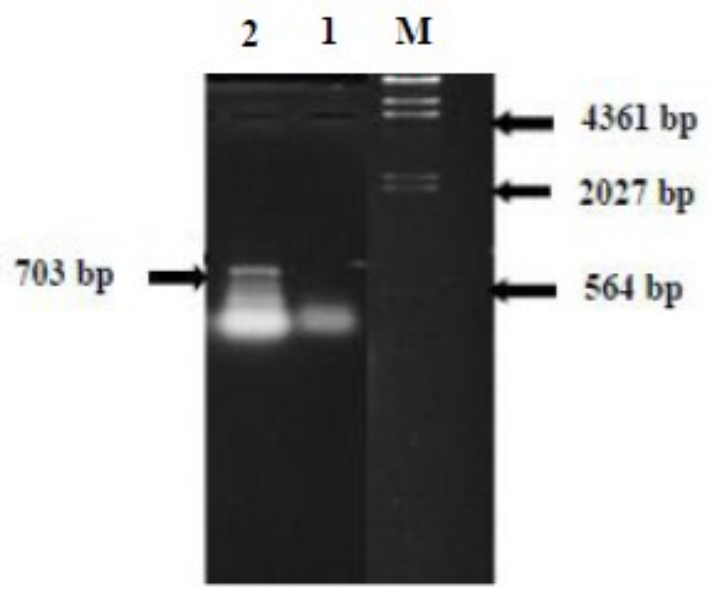

Gambar 3. Hasil elektroforesis pada gel agarosa 0,8\% DNA yang diamplifikasi dengan primer A2 (forward) dan J5 (reverse) dari kontrol air (jalur 1)/ control negatif, DNA diekstraksi dari daun jeruk yang terinfeksi penyakit (jalur 2), M: lamda DNA/HindIII marker.

\section{Pembahasan}

Sampel daun jeruk yang digunakan dalam penelitian ini berhasil dideteksi keberadaan bakteri L. asiaticus pada hasil visualisasi dengan ukuran produk pita DNA target sekitar $1100 \mathrm{bp}$ (Gambar 2), saat diamplifikasi menggunakan primer spesifik 16S rDNA, yaitu primer OI1 dan OI2c. Reaksi positif terlihat pada jalur 1, 3, 4, 5 dan 6 (Gambar 2). Deteksi menggunakan primer spesifik A2 dan J5 dengan target gen protein ribosom, juga menunjukkan reaksi positif pada jalur 3 dengan produk pita DNA target sekitar 703 bp (Gambar 3). Hal ini menunjukkan bahwa sampel daun Jeruk Siam dengan pola gejala klorosis disertai bercak positif terinfeksi bakteri patogen L. asiaticus. Menurut Wijaya (2003), gejala khas dari penyakit daun jeruk yang terinfeksi patogen $L$. asiaticus menunjukkan gejala klorosis (daun menguning), warna tulang daun menjadi hijau tua (vein banding), daunnya lebih tebal, kaku dan ukurannya menjadi lebih kecil yang merupakan gejala dari penyakit CVPD (Citrus Vein Phloem Degeneration) yang disebabkan oleh patogen Liberibacter.

Adapun gejala klorosis yang ditemukan di perkebunan jeruk Kota Singkawang memiliki kemiripan dengan gejala akibat infeksi bakteri patogen $L$. asiaticus. Namun selain gejala klorosis juga ditemukan gejala bercak coklat kehitaman 
pada daun, gejala bercak juga sering ditemukan pada daun jeruk yang terserang penyakit kanker jeruk. Gejala yang dimiliki daun tersebut juga terlihat mirip dengan gejala kanker jeruk. Menurut Davies dan Albrigo (2003) penyakit kanker jeruk atau Citrus Bacterial Cancer (CBC), disebabkan infeksi bakteri patogen Xanthomonas axonoposids pv, dengan gejala yang muncul pada bagian daun, ranting dan buah. Gejala umum penyakit kanker jeruk yaitu tepi bercak berwarna kuning (halo kuning) yang akan berubah menjadi coklat hitam dan terbentuknya lesi nekrotik. Sampel daun jeruk ini menunjukkan pita DNA positif ketika dideteksi dengan dua pasang primer spesifik yaitu OI1 dan OI2c serta primer A2 dan J5 yang merupakan primer spesifik untuk deteksi keberadaa patogen L. asiaticus dari gejala klorosis yang ditimbulkannya.

Hal ini dapat dikatakan bahwa satu sampel daun jeruk bisa terinfeksi lebih dari satu penyakit dan terdapat lebih dari satu bakteri patogen. Menurut Wirawan et al. (2003), bahwa gejala penyakit dengan pola klorosis tidak harus disebabkan oleh keberadaan bakteri patogen, namun tanaman yang positif terinfeksi patogen dapat menyebabkan gejala klorosis pada daun tanaman di sebelahnya, di atas dan dibagian bawah daun tanaman yang tidak terinfeksi. Seperti yang terjadi pada sampel daun Jeruk Siam ini, yang memiliki gejala mirip penyakit kanker jeruk namun terdapat pula gejala klorosis seperti gejala penyakit CVPD, hal ini diduga dapat terjadi akibat tertular daun klorosis di sebelahnya yang lebih dulu terinfeksi patogen $L$. asiaticus.

Penggunaan kedua primer spesifik CVPD ini dikarenan primer tersebut mampu mendeteksi penyakit pada tanaman yang disebabkan oleh keberadaan bakteri patogen di dalam jaringan tanaman dengan target yang terletak pada daerah genomik 16S rDNA (OI1 dan OI2c), dan dengan target gen protein ribosom (A2 dan J5) (Hocquellet et al., 1999), berdasarkan pola gejala penyakit yang ditemukan di perkebunan jeruk Desa Setapok, Kota Singkawang. Penelitian sebelumnya telah dilakukan oleh Meitayani et al. (2014), menggunakan primer spesifik OI1 (forward) dan OI2c (reverse) untuk mengamplifikasi sekuen spesifik pada fragment 16S rDNA untuk strain Asia (L. asiaticus). Selain itu deteksi terhadap patogen $L$. asiaticus juga pernah dilakukan oleh Ruangwong \& Akarapisan (2006), bahwa deteksi terhadap penyakit huang-longbing atau CVPD menggunakan primer spesifik A2 (forward) dan J5 (reverse) untuk target gen protein ribosomal terletak pada daerah genomik 16S rDNA dengan produk sekitar $703 \mathrm{bp}$ pada daun jeruk yang disebabkan oleh bakteri L. asiaticus di Provinsi Chiang Rai, Chiang Mai dan Phare, Thailand. Oleh karena itu, penelitian ini juga menggunakan primer spesifik yang sama untuk mendeteksi patogen $L$. asiaticus. dari daun Jeruk Siam yang bergejala klorosis disertai bercak.

Gejala klorosis yang muncul diduga disebabkan oleh penurunan kandungan klorofil pada tanaman akibat toksin yang dihasilkan bakteri penginfeksi (L. asiaticus). Dugaan ini ditunjang oleh pernyataan Bender et al. (1999), bahwa gejala klorosis pada tanaman lain sperti kedelai, tomat, dan mentimun yang terinfeksi bakteri patogen, diakibatkan oleh toksin yang dihasilkan bakteri tersebut. Menurut Lehninger (1982), proses klorosis terjadi melalui pengikatan dan penginaktifan asam amino atau protein faktor perangkai kloroplas yang terlibat dalam proses transfer elektron menuju kloroplas pada saat fotosintesis, pengikatan asam amino tersebut mengakibatkan kandungan asam amino pada tanaman yang terinfeksi bakteri menjadi rendah, sehingga menurunkan jumlah pembentukan klorofil.

Hal ini menjadi penting karena toksin yang dikeluarkan oleh bakteri patogen L. asiaticus menjadi sangat berbahaya bagi tanaman karena dapat merusak sel tanaman sehingga menganggu pertumbuhan dan produktivitas tanaman jeruk tersebut. Todar (2002), menyatakan bahwa bakteri patogen mengeluarkan toksin dan menyebar ke bagian-bagian lain melalui sistem transportasi dengan cepat, walaupun penyebaran bakterinya cukup lambat. Fletcher dan Wayadande (2002), juga menyatakan bahwa kerusakan sel floem terjadi akibat toksin yang dihasilkan oleh patogen L. asiaticus, dan terjadi peroksidasi lipid membran yang mengakibatkan plasmolisis sel, sehingga menghambat pertumbuhan akar. Selain itu toksin mampu menghambat proses sintesis klorofil dan perkembangan kloroplas, sehingga terganggunya sintesis klorofil dan perkembangan kloroplas membuat daun mengalami klorosis (Finlay, 1992)

Namun gejala klorosis tidak hanya menjadi gejala khas penyakit daun jeruk akibat infeksi patogen $L$. asiaticus saja, tetapi dapat juga menjadi gejala 
penyakit lain dan disebabkan oleh faktor lain. Bove (2006), menyatakan bahwa gejala klorosis yang disebabkan oleh penyakit CVPD tidak bersifat spesifik, karena gejala klorosis yang sama juga dapat disebabkan oleh infeksi patogen lain yaitu Spiroplasma citri, Citrus tristeza virus, dan Phythophthora sp. atau dapat disebabkan oleh defisiensi unsur hara Fe dan Zn. Gejala penyakit yang disebabkan infeksi bakteri patogen menjadi salah satu penyakit yang sangat berbahaya karena dapat menurunkan produktivitas tanaman jeruk dan menyebakan kematian pada tanaman di beberapa sentra perkebunan jeruk di Indonesia, salah satunya di perkebunan jeruk Kota Singkawang yang telah terinfeksi oleh bakteri patogen L. asiaticus setelah dideteksi melalui teknik PCR.

\section{UCAPAN TERIMA KASIH}

Penulis berterima kasih kepada Jurusan Biologi Fakultas Matematika dan Ilmu Pengetahuan Alam, Universitas Tanjungpura untuk fasilitas dan bantuan dalam menyelesaikan penelitian ini. My TACG Bioscience Enterprise (SA0168756-P) untuk bantuan primer yang digunakan dalam penelitian ini. Laboratorium Genomik dan Perbaikan Mutu Tanaman (GPMT) Pusat Penelitian Bioteknologi LIPI atas fasilitas dan izinnya dalam menyelesaikan proses kerja penelitian ini.

\section{DAFTAR PUSTAKA}

Bove, JM, 2006, Huanglongbin: a destructive, newlyemerging, century-old disease of citrus, Journal Plant Phatol, vol. 1, no. 88, hal. 7-37

Bender CL, Alarcon-Chaidez F, \& Gross DC, 1999, Pseudomonas syringae Phytotoxins, mode of action, regulation, and biosynthesis by peptide and Polyketide Synthetases, Microb and Mol, Biol, Rev, June, hal. 266-292

Case, RJ, Boucher, Y, Dahllof, I, Holmstrom, C, Doolittle, WF \& Kjelleberg S, 2007, Use of 16S rRNA and rpoB Genes as Molecular Markers for Microbial Ecology Studies, Applied and Environmental Microbiolgy, no. 73, hal 278-288.

Davies FS, \& LG Albrigo, 2003, Citrus Crop Production in Horticulture 2, CAB International, Weeds, Pests, and disease, vol. 172, hal. 189-202

Direktorat Jenderal Bina Produksi Hortikultura (Dirjenhorti), 2002, Agribisnis jeruk saat ini dan strategi pengembangan ke depan, Semiloka Nasional Pengembangan Jeruk dan Pameran Buah Jeruk Unggulan, Bogor, 10-11 Juli 2002

Finlay BB, 1992, Molecular genetic approaches to understanding bacterial pathogenesis, dalam Hormaeche, CE, Penn CW, \& Smith CJ, (Eds.), Molecular biology of bacterial infection, current status and future perspectives, Cambridge Univ Press, Australia

Fletcher J, \& Wayadande A, 2002, Fastidious vascular-colonizing bacteria, The plant health instructor, vol. 2 hal. 1218-2002

Hocquellet, A, Toorawa, P, Bové, JM \& Garnier, M, 1999, Detection and identification of the two Candidatus Liberobacter species associated citrus huanglongbing by $P C R$ amplification of ribosomal protein genes of the operon, Molecular and cellular probes, no. 13, hal. 373-379

Hung, TH, Wu, M \& Su, HJ, 1999, Detection of fastidious bacteria causing citrus greening disease by nonradioactive DNA probes, Ann, Phytopathol, Soc, Jpn, no. 6, hal. 140-146

Jagoeuix, S, Bove, JM \& Garnier, M, 1996, PCR detection of the two Liberobacter species associated with greening disease of citrus, Molecular and Cellular Probes, no. 10, hal. 4350

Jagoueix, S, Bove, JM \& Garnier, M, 1997, Comparison of the $16 \mathrm{~S} / 23 \mathrm{~S}$ Ribosomal Intergenic Regions of Candidatus Liberobacter asiaticum and Candidatus Liberobacter africanum, The Two Species Associated with Citrus Huanglongbing (Greening) Disease, Int. J. Syst. Bacteriolgy, no. 47, hal. 224-227

Lehninger AL, 1982, Dasar-dasar biokimia, Jilid 1, alih bahasa: Maggi Thenawijaya, Erlangga, Jakarta

Meitayani, Swari, NP, Adiartayasa, W \& Wijaya, IN, 2014, Deteksi penyakit Citrus Vein Phloem Degeneration (CVPD) dengan teknik Polymerase Chain Reaction (PCR) pada Tanaman Jeruk di Bali, Jurnal Agroekoteknolgi Tropica FP UNUD, Denpasar, vol. 3, hal. 2

Ruangwong, O, \& Akarapisan, A, 2006, Detection of Candidatus Liberibacter asiaticus causing citrus huanglongbing disease, Journal of Agricultural Technology, vol. 2, no. 1, hal. 111-120 
Sambrook J, \& Russell DW, 2001, Molecular Cloning, vol. 1, Cold Spring Harbor Laboratory Press, New York.

Schaad NW, Jones JB, \& Chun W, 2001, Laboratory Guide for Identification of Plant Pathogenic Bacteria, APS Press, USA

Todar K, 2002, The Mechanisms of Bacterial Pathogenicity, diakses pada 23 Desember 2003, <http://www.bact.wisc >

Wijaya, IN, 2003, Diaphorina citri Kuwayama (Homoptera:Psyllidae), Bioteknologi dan Perannnya Sebagai Vektor Penyakit CVPD pada Tanaman Jeruk Siam, Disertasi, IPB, Bogor

Wijaya, IN, 2007, Penularan penyakit CVPD (Citrus Vhein Phloem Degeneration) oleh Diaphorina citri Huwayama (Homoptera: Phhyllidae) pada Tanaman Jeruk Siam, Jurnal Agritop, vol. 26, no. 4 , hal. $140-146$

Wirawan IGP, Sulistyowati L, \& Wijaya N, 2003, Mekanisme Tingkat Molekul Infeksi Penyakit CVPD pada Tanaman Jeruk dan Peran Diaphorina citri, KUW Sebagai Vector, Denpasar Lemlit, Universitas Udayana 